\title{
Natural and human-induced predation on Cape Cormorants at Dyer Island
}

\author{
ANNE VOORBERGEN, WILLEM F. DE BOER and LES G. UNDERHILL
}

\section{Summary}

To develop conservation strategies for vulnerable seabird species that need attention, it is important to know which factors influence their breeding productivity. Predation of eggs and chicks can have large influences on seabird reproduction, especially when human disturbance facilitates predation. On Dyer Island, Kelp Gulls Larus dominicanus prey on Cape Cormorant Phalacrocorax capensis eggs and chicks, whereas Cape fur seals Arctocephalus pusillus pusillus prey on Cape Cormorant fledglings in the waters surrounding the island. Kelp Gulls were estimated to predate $3.8 \%$ of the total number of Cape Cormorant eggs and $2.0 \%$ of the chicks on the island. These percentages can be expressed as a loss of $4.8 \%$ of Cape Cormorant fledglings, which is low compared to the estimated $24.3 \%$ mortality of Cape Cormorant fledglings by Cape fur seal predation. Human disturbance facilitated Kelp Gull egg and chick predation and increased the mobbing of cormorant fledglings by Kelp Gulls. Cormorant egg predation by gulls was more frequently reported in the late afternoon. Seal predation was more abundant at the northern side of the island compared to the southern side, was recorded more frequently in the morning, and increased through the breeding season. The altered abundance and distribution of prey, the availability of suitable breeding habitat and mortality from avian cholera, have also influenced the Cape Cormorant's population size. Hence, the possibility that Cape Cormorants may be locked in a predator-pit, where seals and gulls prevent the population from increasing in size, needs further attention.

\section{Introduction}

It has been suggested that seabirds aggregate on breeding sites to exchange information about the location of their dispersed and unpredictable prey (Ward and Zahavi 1973, Clode 1993). Many colonial breeding birds leave the breeding colony in flocks and feed together, suggesting that they exchange cues about where to go and feed while at the colony (Gaston 2004). Despite the advantage of exchanging cues about prey location, breeding in colonies makes seabirds conspicuous to predators (Gaston 2004). On Dyer Island, South Africa, Kelp Gulls Larus dominicanus depredate the eggs and chicks of Cape Cormorants Phalacrocorax capensis. Kelp Gull populations have rapidly increased in recent years (Kirkman 2007), probably due to reduced persecution and increased availability of food from human activities, such as rubbish tips and fishery discards (Steele 1992). Cape fur seals Arctocephalus pusillus pusillus at Dyer Island depredate Cape Cormorant fledglings in the surrounding sea (Marks et al. 1997, Johnson et al. 2006). Cape fur seals were at a low population level at the start of the $20^{\text {th }}$ century, but are now abundant off the west coast of South Africa due to the banning of seal harvesting in 1990 (David et al. 2003). Cape Cormorants seem to be a fairly new prey species of the Cape fur seal, because only a single incident of Cape fur seal killing a Cape Cormorant was reported before 1997 (Shaughnessy 1980). The increase in number of these two predators may have dramatic impacts on the breeding success of Cape Cormorants, and force the species into a predator-pit from which it cannot escape. 
Due to a population decline from c.277,000 pairs to c.72,000 pairs between 1977 and 1996 (Barnes 2000) the Cape Cormorant is classified as 'Near Threatened' (IUCN 2009). The aims of this study were threefold. First we quantified natural Kelp Gull predation, and analysed the factors that influence this predation. Second, we tested whether human disturbance, caused by the routine monitoring patrols for African Penguins Spheniscus demersus on Dyer Island (Underhill 2006), facilitated predation of Kelp Gulls on Cape Cormorant eggs and chicks by disturbing nesting Cape Cormorants. Third, as no information exists on the relative importance of attacks of aerial predators and marine mammals on population declines in seabirds (Johnson et al. 2006), we determined the comparative importance of Kelp Gull and Cape fur seal predation on the Cape Cormorant population. By addressing these aims, we can understand how predators regulate the Cape Cormorant population at Dyer Island, identify the factors that facilitate predation of this colony breeding species, and understand how human disturbance mediates predation risk.

\section{Study area}

The Dyer Island complex $\left(34^{\circ} 41^{\prime} \mathrm{S} ; 19^{\circ} 25^{\prime} \mathrm{E}\right)$ is situated about $5 \mathrm{~km}$ offshore and near Gansbaai, South Africa, and consists of two islands. Dyer Island is the larger island with an area of 20 ha and since 1993, between $43 \%$ and $92 \%$ of the Cape Cormorant population of the western Cape bred annually on Dyer Island, a larger population than at any other colony (Waller and Underhill 2007). Cape Cormorants bred in a large number of relatively small subcolonies scattered over the island. Adjacent to Dyer Island is Geyser Rock, with a breeding colony of Cape fur seals of approximately 60,000 individuals in 2009/2010 (Department of Environmental Affairs unpubl. data). There is no ecotourism to Dyer Island because of its vulnerability to human disturbance; in spite of this, disturbance is caused by monitoring patrols (Underhill 2006).

\section{Methods}

Research on predation on Cape Cormorants by Kelp Gulls and Cape fur seals was conducted during the cormorant breeding season. Kelp Gull predation was monitored during the Cape Cormorant egg and chick period ( 16 October to 17 December 2009), and Cape fur seal predation was monitored during a part of the Cape Cormorant fledgling period (25 December 2009 to 25 January 2010), when fledglings moved to the perimeter of the island and swam in the adjacent sea. Natural Kelp Gull and Cape fur seal predation was monitored from an observation tower placed in the middle of the island and with the use of binoculars and a spotting scope.

\section{Size and number of nests per subcolony}

To calculate the effect of Kelp Gull predation, 12 Cape Cormorant subcolonies of different sizes were monitored for natural predation. Subcolony size potentially influences predation probability because larger subcolonies are more conspicuous and hence more vulnerable to predation (Clode 1993), or because the overabundance of prey (eggs and checks) in large subcolonies might decrease the probability of predation (Oro 1996, Schreiber and Burger 2002). To avoid disturbance, the area $\left(\mathrm{m}^{2}\right)$ of each subcolony was measured after the chicks had fledged. Because the subcolonies had been abandoned by this time, digital pictures were taken during the breeding season and natural landmarks such as stones were used to locate them. Subcolony perimeters were measured with measuring tape. The perimeters and distances between subcolonies were drawn on an ArcGis map, after which the surface areas were calculated. Subcolony sizes were then used to estimate the number of nests per colony, using a density of 3.1 nests $/ \mathrm{m}^{2}$ (Berry 1976).

\section{Breeding synchrony}

Darling (1938) suggested that synchrony in breeding of colony nesting birds reduced predation as a result of a temporary overabundance of prey, leading to higher breeding success. We therefore 
estimated the percentages of cormorant nests with eggs, small chicks, medium chicks or large chicks per subcolony during the breeding season every nine days. "Small" cormorant chicks were defined to have no observable flight feathers and were between zero and two weeks old. "Medium" chicks had flight feathers but no emerged contour feathers and were aged between three and four weeks. "Large" chicks had emergent contour feathers and were five or more weeks old (Williams and Ward 2006).

\section{Kelp Gull predation}

Kelp Gull predation was quantified by monitoring 12 Cape Cormorant subcolonies during four periods of the day: early morning (o7hoo-1ohoo), morning (10hoo-13hoo), afternoon (13hoo16hoo) and late afternoon (16hoo-19hoo). During these periods, subcolonies were monitored for 20 minute periods each; two colonies could be observed simultaneously.

The focus was on three specific behaviours: Kelp Gull "attack", Kelp Gull "harassment", and Kelp Gull "food stealing". An "attack" took place when the Kelp Gull was intent on obtaining one or more eggs or chicks in the cormorant nest. An "attack" was defined as either successful or failed. "Harassment" took place when the gull was trying to confuse the cormorant by hovering above the nest with its feet in a downwards position or by running towards the nest. "Food stealing" occurred later in the breeding season when adult cormorants returned to the colony from a feeding trip, and food was being transferred from adult to chick. Kelp Gulls tried to steal the food from the cormorants. During these events the following data were recorded if applicable: time, attack position of Kelp Gull, the number of nests between the perimeter of the subcolony and the nest being attacked, the contents of nest, the success or failure of the attack, the number of eggs/chicks taken, the number of Kelp Gulls involved and the behaviour of the cormorants. This behaviour was recorded as defensive, when the cormorants clearly defended their nests against attacking gulls, or passive, when cormorants did not show defensive actions.

During a monitoring session of a Cape Cormorant subcolony, the behaviour of each Kelp Gull within 2-3 $\mathrm{m}$ of the edge of the subcolony was recorded every $5 \mathrm{~min}$. This behaviour was classified as sitting, standing, searching for and eating cormorant pellets, hovering, or standing near a chick crèche. This latter behaviour took place later in the season, when Kelp Gulls were waiting for the opportunity to steal the food while an adult cormorant fed a chick. Date, time, temperature, wind direction, wind strength, cloud cover, precipitation and state of tide were also recorded. Time, temperature, wind direction, wind strength and tide state might affect gull activity, or the success of a predation attempt. The state of the tide could influence the predation rate, because during low tide alternative food resources become available on the shore. Cloud cover and precipitation can affect visibility of gulls or influence nest occupancy rates and were therefore included in the model as explanatory variables.

\section{Human disturbance}

Human disturbance can interrupt incubation, affect nestling care or increase the exposure to environmental factors or predators (Burger and Gochfeld 1991). Human disturbance may therefore facilitate predation of Cape Cormorant by Kelp Gulls.

Monitoring of Kelp Gull predation on Cape Cormorant nests was therefore also undertaken during routine monitoring patrols. These patrols were conducted by a ranger to count the number of moulting African Penguins Spheniscus demersus. The Kelp Gull predation induced by human disturbance was monitored by AV, by accompanying the ranger during patrols on 9,18 and 23 November and 8 December 2009. The numbers of eggs and chicks that were predated were recorded.

\section{Cape fur seal predation}

Cape fur seal predation was quantified by monitoring part of the coastline of Dyer Island from o7hoo-19hoo. The monitored area covered approximately $36 \%$ of the coastline of Dyer Island; 
half of this area was on the north side of the island; the other half on the south side. This area was chosen because of the good visibility from the tower. A seal predation monitoring session consisted of two hours of observation, spending one hour on each side of the island. Although weather dependent, there were two monitoring sessions per day. During the study period (25 December-25 January), the only prey available to seals in the sea adjacent to Dyer Island were Cape Cormorant fledglings (Makhado 2009).

Seal predation was easily detected, because Kelp Gulls gathered at these events and hovered above the water while waiting to eat whatever is discarded by the seal (du Toit et al. 2004, Makhado 2009). A flock of hovering gulls was considered a Cape Cormorant predation event only if the seal involved was also spotted. On most occasions the cormorant fledgling was observed because Cape fur seals shake their prey vigorously to loosen the skin from the cormorant's torso. In the monitored area, total numbers of fledglings in the water were counted every 15 minutes. Seal predation and total numbers of fledglings in the water were recorded as far into the open ocean as feasible. Apart from weather information, the height of the swell and sea state were also recorded, because these factors may influence seal activity and prey detection.

\section{Comparative importance between predators}

The difference in relative impact of the two predators on Cape Cormorant breeding success on Dyer Island was determined by extrapolating the observed predation by Kelp Gulls on the eggs on chicks and observed predation by Cape fur seals on the fledglings to the whole island for the entire breeding period. The total number of nests in the observed colonies was calculated by using the measured subcolony sizes and nest density of 3.1 nest $/ \mathrm{m}^{2}$ (Berry 1976). The total number of nests on the island was counted by staff of the Oceans and Coasts Branch of the Department of Environmental Affairs during the 2009/2010 breeding season, while cormorants were incubating. The total number of eggs was calculated by multiplying the number of nests by 2.36 (average eggs/nest (Crawford, 2005). These numbers were then used to extrapolate the egg and chick predation rate per observation hour to the entire Cape Cormorant population at Dyer Island. When extrapolating the egg predation effect, it was assumed that egg predation occurred during daylight for $12 \mathrm{~h}$ /day for an incubation period of 25 days. To extrapolate the impact of chick predation, we assumed that chick predation took place for $12 \mathrm{~h} /$ day for 28 days, after which chicks are large enough to be less susceptible to gull predation.

To extrapolate the Cape fur seal predation from the observation period to the whole fledgling period, it was assumed that seal predation took place during daylight ( $12 \mathrm{~h} /$ day) for the fledging period of the cormorants, from 25 December to 25 February (63 days). We took into account differences in predation rate to the north and south of the island. We extrapolated the number of predated fledglings on the north side of the monitored area to the northern perimeter, and similarly to the northern perimeter. The remaining coast sections (east and west) were assumed to have a predation rate equivalent to the mean recorded predation rate at the south and north side.

For the comparison of the Kelp Gull and Cape fur seal predation, the numbers of eggs and chicks predated by Kelp Gulls were extrapolated to the number of fledglings, using Crawford's (2005) observed mean values of hatching success (0.87) and fledging success (0.91).

\section{Statistical analyses}

Statistical analyses were done using SPSS 15.0 and R (v2.9.2; R Development Core Team 2011). A binary logistic regression was used to test for the impacts of subcolony size, day in sequence of breeding season, part of the day, temperature, wind strength, precipitation and tide state, on observations (20 minute scanning period) with or without Kelp Gull egg or chick predation. Also, the impact of these explanatory variables on observations with or without Kelp Gull predatory behaviour (attack, harassment, food stealing) was tested using binary logistic regression. A binary logistic regression analysis was also used to test for the impact of the number of Kelp Gulls 
involved, attack position, cormorant behaviour, nest contents and distance of nest from the perimeter, on the success/failure of attacks. Impact of the number of Kelp Gulls involved, attack position and cormorant behaviour on the success/failure of stealing food swaps, were also tested with a binary logistic regression. A Mann-Whitney $U$ test was used to test for differences in seal predation between the north and south side of the island, because the data did not follow a normal distribution. A binary logistic regression was used to test for the impacts of period of day, side of the island, day in sequence of breeding season, cloud cover, tide state, swell height, sea state, mean number of fledglings in the water on the one-hour observations with or without seal predation. For all logistical analyses we reported the percentage correctly predicted cases, as a relative measure of fit of the best model. We used the bestglm function in R (R Development Core Team 201I) to find and compare the best five models with the lowest AIC for each of the logistic regressions. However, these five models were all relatively similar, because they only differed in the number of non-significant variables that was included in each of the models. We therefore reported only the model in which all variables were significant.

A Generalized Linear Model (GLM) was used to test for the impacts of these variables on the frequency of seal predation event per observation period, using a Poisson distribution for the dependent variable and a logarithmic link function. The numerous observations without seal predation were omitted from this latter analysis, to avoid violations of the GLM assumptions with regard to the data distribution.

\section{Results}

\section{Breeding synchrony}

When the monitoring of Kelp Gull predation started on 16 October 2009, most cormorants were incubating eggs. Some subcolonies had nests with small chicks by that time; these eggs were laid in the middle of September. As the breeding season progressed, subcolonies became larger and eggs were still being laid while some chicks were about to fledge. Nests with eggs were observed until 17 December, but these nests were not successful, because all subcolonies had only large chicks by 27 December.

\section{Egg and chick predation rate}

In total 75 monitoring sessions of 20 min were conducted in each of the 12 subcolonies. Subcolony size ranged from $20 \mathrm{~m}^{2}$ to $380 \mathrm{~m}^{2}$, yielding a range from 62 to 1,178 nests per subcolony. The mean predation rate for eggs and chicks was respectively 0.11 eggs/h and 0.04 chicks/h during an incubation time of 28 days.

\section{Effect of human disturbance}

Egg predation rates of 36.4, 4.0, 5.1 and 10.1 eggs/h and a chick predation rates of 1.0, 1.1, 0.0 and 0.0 chicks/h were recorded during the four penguin moult counts. These predation rates represent minimum estimates, because of poor visibility of predation events from the ground. The number of cormorants on eggs was largest during the first moult count, but there were still cormorant nests with eggs during the remaining moult counts. During the final two moult counts, when Cape Cormorant fledglings moved to the perimeter of the island, Kelp Gulls mobbed the fledglings when human disturbance took place. In reaction, fledglings started to regurgitate their food and gulls took advantage of this. The frequency of mobbing events was high and seemed certain to have been associated with human disturbance, because it was never seen during monitoring of natural Kelp Gull predation.

\section{Effect of other variables}

A binary logistic regression was used to test for the relation between an egg predation event as the dependent variable, and subcolony size, time of day, day in sequence of breeding season, 
temperature, wind strength, precipitation and tide height as explanatory variables. The analysis showed that time of day had a statistically significant relation with the event of egg predation $\left(\%\right.$ correctly predicted cases $=96.8 \%, n=728$, Wald $_{\text {part }}=9.259, \mathrm{df}=3, P<0.05$; Figure 1a $)$, because most $(64 \%)$ predation took place between 16 hoo and 19hoo. Subcolony size, day, temperature, wind strength, precipitation and tide state did not have a statistically significant effect on egg predation.

A similar analysis was used to test for the impact of these explanatory variables on chick predation events. Subcolony size had a statistically significant relationship with chick predation ( $\%$ correctly predicted cases $=98.9 \%$, Wald $\left._{\text {size }}=12.447, \mathrm{df}=1, P<0.05\right)$; the larger the subcolony, the more frequently chick predation events were recorded. Time of day, day, temperature, wind strength, precipitation and tide state did not have a statistically significant relation to the occurrence of chick predation.

We tested for the relation between the occurrence of three predatory behaviours (attack, harassment and food stealing) as dependent variables, and subcolony size, part of day, day, temperature, wind strength, precipitation and tide state as explanatory variables. The analysis showed that subcolony size and the day in sequence of breeding season had a positive effect on the occurrence of an event (binary logistic regression, $\%$ correctly predicted cases $=71.1 \%, n=283$, Wald $_{\text {size }}=74.587, \mathrm{df}=1, P<0.01 ;$ Wald day $_{18}=18.195, \mathrm{df}=1, P<0.01$ ), more events took place
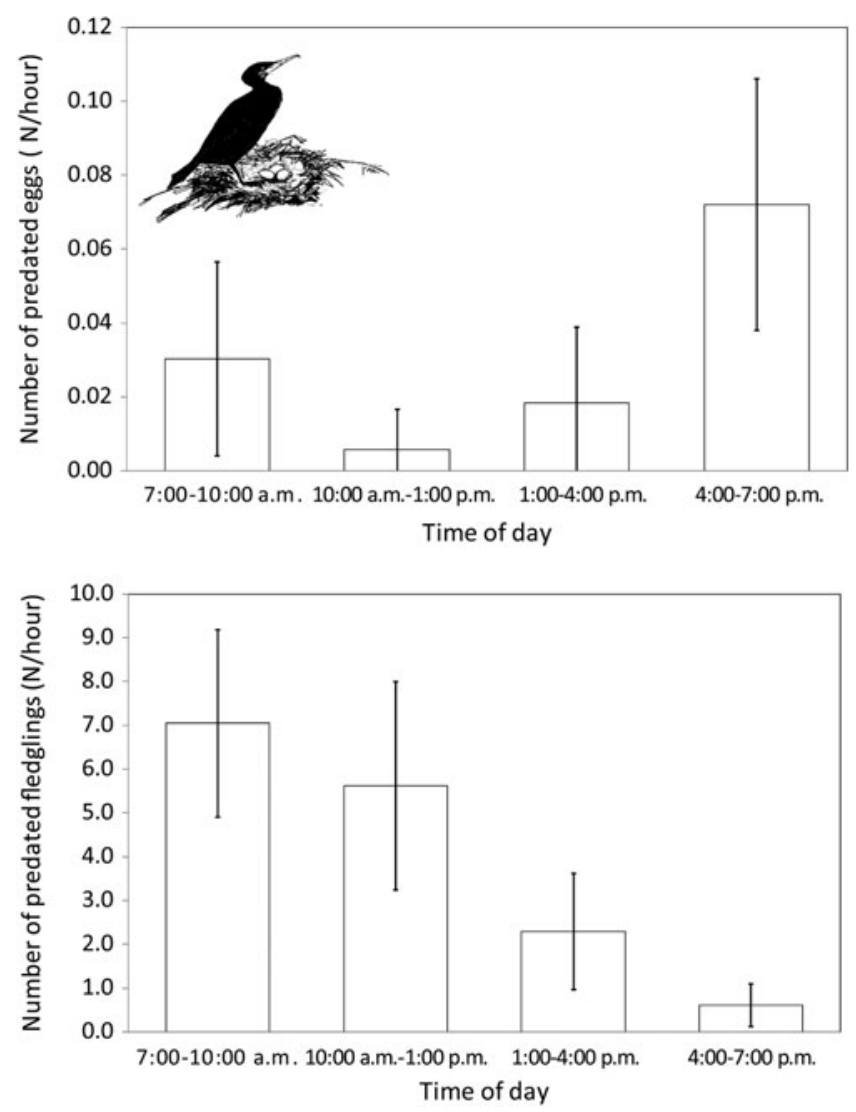

Figure 1. Relation between the time of day and the mean ( $\pm 95 \% \mathrm{CL}$ ) number of eggs predated by Kelp Gulls (Ia), and number of predated fledglings by Cape fur seals (Ib). 
at larger subcolonies and as the breeding season progressed. Significantly more events also took place when it rained and with stronger winds $\left(\right.$ Wald $_{\text {prec }}=9.893, \mathrm{df}=1, P<0.05 ; \mathrm{Wald}_{\text {wind }}=$ $15.728, \mathrm{df}=4, P<0.05$ ). Other environmental variables were not significant. The success of an attack, i.e. an attempt of egg or chick predation, was analysed in a separate analysis, but was found to be independent of the distance of the nest from the perimeter of the subcolony, number of Kelp Gulls involved, attack position, cormorant behaviour and nest contents.

The attack position of the Kelp Gull and cormorant behaviour were related to the success of food stealing ( $\%$ correctly predicted cases $=87.5 \%, n=97$, Wald pos $_{1}=11.091, \mathrm{df}=1, P<0.05$; Wald $\left._{\text {beh }}=4.487, \mathrm{df}=1, P<0.05\right)$. Attacks of Kelp Gulls from the air were more successful in stealing food than attacks from the ground; defensive behaviour of the cormorants lead to less successful Kelp Gull attacks than when cormorants showed passive behaviour.

\section{Cape fur seal predation}

In total, $36 \%$ of the island's coastline was monitored, $18 \%$ on the north and $18 \%$ on the south. During 43 hours of observation on each side, 94 and 234 cormorant fledglings were predated by Cape fur seals on the south and north side respectively. There was a difference in predation rate between the two directions, with less predation on the south side compared to the northern side of the island (Mann-Whitney $\mathrm{U}=553.5, n=86, P<0.05$ ).

Time, day, and side of the island were correlated with the occurrence of a seal predation event ( $\%$ correctly predicted cases $=79 \%, n=63$, Wald $_{\text {part }}=9.273, \mathrm{df}=3, P<0.05 ;$ Wald $_{\text {day }}=$ $4.408, \mathrm{df}=1, P<0.05 ;$ Wald $\left._{\text {side }}=10.533, \mathrm{df}=1, P<0.05\right)$. Observations of seal predation were more frequently reported in the morning (Figure $\mathrm{Ib}$ ), as the breeding season progressed, and on the north side of the island compared to the south side. Cloud cover, tide state, height of swell, sea state and mean number of fledglings in the water were not significantly related to seal predation. The frequency of predation was higher in the morning, higher at the north side of the island, and increased through the breeding season (GLM; deviance/df $=1.454, n=52, \mathrm{Wald}_{\text {part }}=45.234$, $\mathrm{df}=3, P<0.01 ;$ Wald $_{\text {day }}=25.535, \mathrm{df}=1, P<0.01 ;$ Wald $\left._{\text {side }}=7.244, \mathrm{df}=1, P<0.01\right)$.

\section{Kelp Gull vs Cape fur seal predation}

The total number of nests at the 12 cormorant subcolonies was estimated to be 4,476 . The total number of nests on the whole island was estimated to be 36,283 on 2 November 2009 (Bruce M. Dyer, Oceans and Coasts in litt.) so $12.3 \%$ of all nests was monitored for natural Kelp Gull predation. Extrapolation of the observed egg predation rate to a day of $12 \mathrm{~h}$ for the incubation period of 25 days, yielded an estimated total of 406 eggs which would have been subject to natural predation over the monitored area. Extrapolating this figure to the whole island yields an estimate of 3,293 eggs (3.8\% of all eggs) that would have been predated by Kelp Gulls. Chick predation was estimated in a similar way, using a chick period of 28 days. An estimated total of 180 chicks were predated over the monitored area and an estimated 1,456 chicks $(2.0 \%)$ over the whole island. The $3.8 \%$ egg predation and the $2.0 \%$ chick predation by Kelp Gulls can be expressed as a loss of 3,270 (4.8\%) fledglings, using the hatching and fledging rates estimated by Crawford (2005).

Seal predation per hour was extrapolated to $12 \mathrm{~h} /$ day and to the 63 -day fledging period. An estimated 5,815 fledglings were predated over the monitored area. Extrapolating this to the whole island, taking into account the differences between predation rates over the island, a total of 16,493 fledglings were estimated to have been predated by Cape fur seals during the 2009/1o breeding season. By using the hatching and fledgling rates, the peak nest count of Cape Cormorants of 36,283 nests could produce a fledgling population of 67,792 fledglings over the whole breeding season. So Cape fur seals were estimated to have removed $24.3 \%$ of the fledgling population, which is five times larger than the estimation of $4.8 \%$ fledglings predated by Kelp Gulls. 


\section{Discussion}

\section{Breeding synchrony}

Cape Cormorants did not breed synchronously within the subcolonies; eggs were laid when chicks of the same subcolony were about to fledge. Thus, the abundance of prey was spread, increasing the vulnerability of nests to predation. Because breeding was asynchronous within subcolonies, Kelp Gull egg predation was probably underestimated, because the monitoring of egg predation also covered nests that already had chicks. Similarly, the monitoring of chick predation also covered nests that still contained eggs.

\section{Kelp Gull predation}

We estimated that Kelp Gulls predated 3,293 eggs and 1,456 chicks at Dyer Island during the 2009/1o breeding season. Kelp Gulls have been previously reported to kleptoparasitise other seabird and shorebird species (Hockey 1980, Duffy 1983), and kleptoparasitism by Kelp Gulls turned out to be a common feeding strategy on Dyer Island; while the cormorant breeding season progressed, incidents of food stealing were observed more frequently. Single Kelp Gulls remained at the periphery of a cormorant subcolony, near a cormorant crèche and stole food from adult cormorants while they were transferring food to their chicks. This behaviour was also reported in a study, in which Kelp Gulls stole $8.8 \%$ of food brought to tern colonies (Quintana and Yorio 1999).

Time was an important factor determining the rate of natural Kelp Gull egg predation. Most of the egg predation took place in the late afternoon and early evening before Cape Cormorants returned from their last feeding trip.

\section{Human disturbance}

Kelp Gull predation was difficult to monitor during penguin moult counts because Kelp Gulls reacted quickly and the field of view was limited from the ground. Human-induced gull predation during moult counts was therefore probably underestimated, compared to natural gull predation monitored from an observation tower with a better view. Nevertheless, we showed that human disturbance facilitated predation, because the human-disturbed egg predation rate by Kelp Gulls was 100-200 times greater than the natural egg predation rate and the chick predation rate was about too times larger than the natural chick predation rate. This corresponds with a study of gull predation on Eider ducklings Somateria mollissima where the gull predation rate on duckling crèches was 200-300 times greater on disturbed than on undisturbed crèches (Ahlund and Gotmark 1989). Speed of the moving object causing disturbance can be an important factor determining the reaction of birds to disturbance (Bellefleur et al. 2009); cormorants on Dyer Island appeared to be less susceptible to disturbance when the observers undertaking the monitoring moved slowly during penguin moult counts. Nevertheless, predation by Kelp Gulls was unavoidable when performing penguin moult counts on the island.

Not many cormorant chicks were predated during the four moult counts. The parents seemed determined to defend their nest when they had small chicks; in contrast, many cormorants left nests containing eggs when disturbed. This better parental defence of chicks compared to eggs has been recorded in other bird species (Galeotti et al. 2000, Weston and Elgar 2005). Indeed, sometimes cormorant nests with newly laid eggs were completely predated after human disturbance.

As well as facilitating Kelp Gull predation, human disturbance caused stress in cormorants; medium sized chicks left their nests and fled into the colony, where they were harassed by adult cormorants. Also, cormorant fledglings fled into the water when being approached by the patrol and often regurgitated their food because of stress. In the study by Albores-Barajas et al. (2009), chicks of Cassin's Auklet Ptychoramphus aleuticus stopped gaining weight sooner, and fledged at 
lower weights, when human disturbance was present. As the survival of fledglings is likely to be affected by their mass (Albores-Barajas et al. 2009), it is possible that human disturbance on Dyer Island also negatively affected the survival of cormorant fledglings.

\section{Cape fur seal predation}

Cormorant fledglings were vulnerable to predatory seals when swimming in the waters adjacent to Dyer Island. According to du Toit et al. (2004) cormorant fledglings do not associate seals with danger. In a study by Marks et al. (1997), the reaction of cormorant fledglings to predators also seemed to be minimal. Similar naïve behaviour of Bank Cormorant Phalacrocorax neglectus fledglings, Cape Cormorants and African Penguins Spheniscus demersus towards killer whales Orcinus orca was reported by Williams et al. (1990). Consequently, an estimated $24.3 \%$ of the fledglings for the 2009/1o breeding season were preyed upon. This is large compared to the estimate made during the $1994 / 95$ cormorant breeding season, when $7.3 \%$ of the fledglings were estimated to be predated by Cape fur seals (Marks et al. 1997). Their estimate was based on collecting fledgling carcasses on the shoreline of Dyer Island and was therefore probably an underestimate, because an unknown proportion of carcasses do not wash up. Johnson et al. (2006) estimated the Cape fur seal predation at $0.83-1.09 \%$ of the Cape Cormorant fledgling population at Dyer Island during 1999. This estimate was also based on collecting carcasses and on opportunistic observation of attacks. During the breeding season of 2004 and 2006/o7, it was estimated by (Makhado 2009) that $4-8 \%$ of cormorant fledglings were predated on by Cape fur seals. This estimate was based on observations of attacks. Although our estimate of Cape fur seal predation was higher than other seal predation studies on Dyer Island, the Cape fur seal predation at Malgas Island, South Africa, was estimated to be $29 \%, 83 \%$ and $57 \%$ of the overall production of Cape Gannet Morus capensis fledglings (Makhado et al. 2006). These estimations were based on observations from the 2000/01, 2003/04 and 2005/06 breeding seasons respectively and confirm that seabird fledglings are vulnerable to Cape fur seal predation.

Similar to the observations of Makhado (2009) time of day had an important effect on predation by Cape fur seals and most predation was observed in the morning. Side of the island was also an important factor and more attacks on fledglings were recorded along the sheltered northern side. This difference in seal predation rate between sides of the island is also reported by Makhado (2009).

Similar to the observations of Marks (et al. 1997) at least two of the observed cases of seal predation resembled 'play' behaviour. More seals were involved during those predation events and the predated cormorant was repeatedly tossed into the air and exchanged between the seals. Marks et al. (1997) suggested this was teaching behaviour by an adult to juvenile Cape fur seals.

\section{Conservation implications}

Steele (1992) attributed the increase in the Kelp Gull population of South Africa partly to the availability of food from human activities, including open rubbish tips. Studies elsewhere also mention open rubbish tips in coastal towns as a stable source of food for Larus species (Kihlman and Larsson 1974, Bergman 1982). Studies have shown that closing rubbish tips can negatively affect breeding success of Larus species (Pons 1992, Kilpi and Ost 1998).

The estimated impact of Cape fur seal predation is five times larger than the estimated impact of Kelp Gull predation (24.3\% and $4.8 \%$ respectively). Our seal mortality estimation is high compared to earlier studies on Dyer Island, and suggests an increase in seal predation. Marks et al. (1997) noted that the apparent increase in seal predation on birds in southern Africa was correlated with the marked increase in seal populations. Alternatively, they suggested that increased seal predation may be an indication of a reduction in other stable food resources like hake Merluccius spp. The availability of sardines Sardinops sagax along South Africa's west coast 
declined after 2000 and coincided with a marked eastward shift in the distribution of this species (van der Lingen et al. 2005). Because sardines are fed upon by Cape fur seals, the eastwards displacement may have caused seals to feed more intensively on alternative prey such as cormorant fledglings, which are easily caught (Navarro 2000). On the other hand, only sub-adult male seals predated seabirds (du Toit et al. 2004, Makhado et al. 2006), so only a tiny fraction of the seal population was engaged in killing seabirds and the larger part of the seal population still took prey other than seabirds.

Although seals and gulls predated a substantial number of cormorant eggs, chicks and fledglings at Dyer Island during the breeding season of $2009 / 10$, these predators are probably not the only factors responsible for the overall Cape Cormorant population decline. From the mid 199os there was a large reduction in the number of Cape Cormorant breeding pairs in the Western Cape (Crawford et al. 2007). A variety of factors such as the altered abundance and distribution of prey, the availability of suitable breeding habitat and mortality from avian cholera (Waller and Underhill 2007), have clearly influenced the population size of Cape Cormorants (Crawford et al. 2007). The possibility that cormorants are locked in a predator-pit, where seals and gulls prevent the population from increasing in size, needs further attention.

\section{Acknowledgements}

For permission to work on Dyer Island, and the use of facilities and logistical support we thank CapeNature, and for local support we thank Coral Birss, Deon Geldenhuys and Dr Lauren Waller (CapeNature). Thanks to CapeNature's field rangers for their cooperation during the fieldwork: Mariëtta Lintnaar, Piet Simons, Johny Brander, Dolf Europa, Nickolaas Barry.

\section{References}

Ahlund, M. and Gotmark, F. (1989) Gull predation on eider ducklings Somateria mollissima, effects of human disturbance. Biol. Conserv. 48: 115-127.

Albores-Barajas, Y. V., Soldatini, C. and Furness, R. W. (2009) Are burrow nesting seabird chicks affected by human disturbance? Waterbirds 32: 572-578.

Barnes, K. N. (2000) The Eskom Red Data Book of birds of South Africa, Lesotho and Swaziland. Johannesburg: BirdLife South Africa.

Bellefleur, D., Lee, P. and Ronconi, R. A. (2009) The impact of recreational boat traffic on Marbled Murrelets (Brachyramphus mamoratus). J. Environ. Manage. 90: 531-538.

Bergman, G. (1982) Population dynamics, colony formation and competition in Larus argentatus, fuscus and marinus in the archipelago of Finland. Ann. Zool. Fenn. 19: 143-164.

Berry, H. H. (1976) Physiological and behavioural ecology of the Cape Cormorant Phalacrocorax capensis. Madoqua 9: 5-55.
Burger, J. and Gochfeld, M. (1991) The Common Tern: its breeding biology and social behavior. New York: Columbia University Press.

Clode, D. (1993) Colonially breeding seabirds predators or prey. Trends Ecol. Evol. 8: 336338.

Crawford, R. J. M. (2005) The Cape cormorant. Roberts' birds of southern Africa. $7^{\text {th }}$ edition. Cape Town: John Voelcker Bird Book Fund.

Darling, F. F. (1938) Bird flocks and the breeding cycle. Cambridge, UK: Cambridge University Press.

David, J. H. M., Cury, P., Crawford, R. J. M., Randall, R. M., Underhill, L. G. and Meyer, M. A. (2003) Assessing conservation priorities in the Benguela ecosystem, South Africa: analysing predation by seals on threatened seabirds. Biol. Conserv. 114: 289-292.

du Toit, M., Bartlett, P. A., Bester, M. N. and Roux, J.-P. (2004) Seabird predation by individual seals at Ichaboe Island, Namibia. S. Afr. J. Wildl. Res. 34: 45-54. 
Duffy, D. C. (1983) The foraging ecology of Peruvian seabirds. Auk 100: 800-810.

Galeotti, P., Tavecchia, G. and Bonetti, G. (2000) Parental defence in Long-eared Owls Asio otus: effects of breeding stage, parent sex and human persecution. J. Avian Biol. 31: 431-440.

Gaston, A. J. (2004) Seabirds. A natural history. London: T \& A D Poyser.

Hockey, P. A. R. (1980) Kleptoparasitism by Kelp Gulls Larus dominicanus of African Black Oystercatchers Haematopus mochini. Cormorant 8: 97-98.

IUCN (2009) IUCN Red List of threatened species. Version 2009.1.

Johnson, R. L., Venter, A., Bester, M. N. and Oosthuizen, W. H. (2006) Seabird predation by white shark, Carcharodon carcharifas, and Cape fur seal, Arctocephalus pusillus pusillus, at Dyer Island. S. Afr. J. Wildl. Res. 36: 23-32.

Kihlman, J. and Larsson, L. (1974) On the importance of refuse dumps as a food source for wintering Herring Gulls Larus argentatus Pont. Ornis Scand. 5: 63-70.

Kilpi, M. and Ost, M. (1998) Reduced availability of refuse and breeding output in a herring gull (Larus argentatus) colony. Annal. Zool. Fenn. 35: 37-42.

Kirkman, S. P., ed. (2007) Final report of BLCME (Benguela Current Large Marine Ecosystem) Project on top predators as biological indicators of ecosystem change in the BCLME. Cape Town: Avian Demography Unit.

Makhado, A. B. (2009) Investigation of the impact of fur seals on the conservation status of seabirds at islands off South Africa and at the Prince Edward Islands. $\mathrm{PhD}$ Thesis. University of Cape Town, Department of Zoology.

Makhado, A. B., Crawford, R. J. M. and Underhill, L. G. (2006) Impact of predation by Cape fur seals Arctocephalus pusillus pusillus on Cape gannets Morus capensis at Malgas Island, Western Cape, South Africa. Afr. J. Mar. Sci. 28: 681-687.

Marks, M. A., Brooke, R. K. and Gildenhuys, A. M. (1997) Cape fur seal (Arctocephalus pusillus pusillus) predation on Cape cormorants (Phalacrocorax capensis) and other birds at Dyer Island, South Africa. Mar. Ornithol. 25: 9-12.

Navarro, R. A. (2000) Cape fur seal predation on Cape Gannet fledglings. Bird Numbers 9: 15-16.

Oro, D. (1996) Colonial seabird nesting in dense and small sub-colonies: An advantage against aerial predation. Condor 98: 848850.

R Development Core Team (2011) R: a language and environment for statistical computing. Version 2.9.2 Vienna, Austria: R Foundation for Statistical Computing.

Pons, J. M. (1992) Effects of changes in the availability of human refuse on breeding parameters in a herring gull (Larus argentatus) population in Brittany, France. Ardea 80: 143-150.

Quintana, F. and Yorio, P. (1999) Kleptoparasitism by Kelp Gulls on Royal and Cayenne Terns at Punta Leon, Argentina. J. Field Ornithol. 70: 337-342.

Schreiber, E. A. and Burger, J. (2002) Biology of marine birds. Florida: CRC Press LLC.

Shaughnessy, P. D. (1980) Influence of Cape fur seals on Jackass Penguin numbers at Sinclair Island. S. Afr. J. Wildl. Res. 10: 18 21.

Steele, W. K. (1992) Diet of Hartlaub's gull Larus hartlaubii and the Kelp gull Larus dominicanus in the southwestern Cape province, South Africa. Ostrich 63: 68-82.

Underhill, L. G. (2006) Seabird sites in southern Africa. Dyer Island. Cape Town: Animal Demography Unit.

van der Lingen, C. D., Coetzee, J. C., Demarcq, H., Drapeau, L., Fairweather, T. P. and Hutchings, L. (2005) An eastward shift in the distribution of southern Benguela sardine. GLOBEC International Newsletter 11: 17-22.

Waller, L. J. and Underhill, L. G. (2007) Management of avian cholera Pasteurella multocida outbreaks on Dyer Island, South Africa, 2002-2005. Afr. J. Mar. Sci. 29: 105-111.

Ward, P. and Zahavi, A. (1973) The importance of certain assemblages of birds as "Information Centers" for food finding. Ibis 115: 517-534.

Williams, A. J. and Ward, V. L. (2006) Sacred Ibis and Gray Heron predation of Cape 
Cormorant eggs and chicks; and a review of ciconiiform birds as seabird predators. Waterbirds 29: 321-327.

Williams, A. J., Dyer, B. M., Randall, R. M., and Komen, J. (1990) Killer whales Orcinus orca and seabirds: 'play', predation and association. Mar. Ornith. 18: 37-41.

Weston, M. A. and Elgar, M. A. (2005) Parental care in Hooded Plovers (Thinornis rubricollis). Етu 105: 283-292.

\section{ANNE VOORBERGEN, WILLEM F. DE BOER*}

Resource Ecology Group, Wageningen University, Droevendaalsesteeg $3 a, 6708$ PB Wageningen, The Netherlands.

LES G. UNDERHILL

Animal Demography Unit, Department of Zoology, University of Cape Town, Rondebosch 7701, South Africa.

${ }^{*}$ Author for correspondence; email: fred.deboer@wur.nl

Received 24 February 2011; revision accepted 4 December 2011 